\title{
Wildlife numbers on late and mid seral Chihuahuan Desert rangelands
}

\author{
T. NELSON, J.L. HOLECHEK, R. VALDEZ, AND M. CARDENAS
}

Authors are graduate research assistant and professor, Department of Animal and Range Sciences; professor, Department of Fishery and Wildlife Sciences; and professor, Department of Experimental Statistics, New Mexico State University, Las Cruces, N.M. 88003.

\section{Abstract}

Seasonal wildlife observations were made along transects on 2 pastures in late seral and 2 pastures in mid seral condition in southcentral New Mexico in non-drought and drought years (1993, 1994). Remaining climax vegetation was about $64 \%$ and $57 \%$ on late seral pastures. About $37 \%$ and $32 \%$ of the climax vegetation remained on mid seral pastures. Total wildlife and total bird sightings $/ \mathrm{km}^{2}$ during the study period were higher $(P<0.10)$ on the mid compared to late seral rangelands. The same number of wildlife species were seen on the late and mid seral pastures. Sightings of scaled quail (Callipepla squamata Vigors), mourning doves (Zenaida macroura Linnaeus), pronghorn (Antilocapra americana Ord), and desert cottontails (Sylvilagus auduboni Mearns) showed no differences (P > 0.10) between late and mid seral condition rangelands. Black-tailed jackrabbit (Lepus californicus J.A. Allen) numbers were higher $(P<0.10)$ on mid than late seral pastures. Drought conditions in 1994 severely depressed $(P<0.01)$ total wildlife sightings $/ \mathrm{km}^{2}$ compared to 1993 when precipitation conditions were near average. Year effects were significant $(P<0.10)$ for black-tailed jackrabbit, mourning dove, raven (Corvus corax Gmelin), total songbird, total bird, and total wildlife sightings. Total wildlife sightings in 1994 were reduced by $42 \%$ compared to 1993 (256 versus 440 total sightings $\mathbf{k m}^{2}$, respectively).

Key Words: grazing, arid lands, songbirds, jackrabbits, quail, pronghorn

Chihuahuan Desert rangelands are important for both livestock production and recreation in New Mexico. They support about $20 \%$ of the beef cow herd in New Mexico. The Chihuahuan Desert is a primary source of clean air, recreation, wildlife, and esthetics to a rapidly expanding Southwestern human population. Increasingly, livestock production in New Mexico and other western states is being challenged by environmentally concerned groups. Various wildlife species on both public and private rangelands in the Chihuahuan Desert are becoming increasingly important as sources of recreation and income (Cutler 1990). Therefore knowledge of the impact of different livestock grazing strategies on wildlife habitat in the Chihuahuan Desert is important in range management decisions.

Chihuahuan Desert rangelands in late seral condition may pro-

This research was supported by the New Mexico Agr. Exp. Sta., Las Cruces, New Mexico and was part of project 1-5-27417.

Manuscript accepted 7 Dec. 1996.

\section{Resúmen}

Observaciones de fauna silvestre fueron realizadas en diferentes estaciones del año a lo largo de transectos establecidos en cuatro potreros; 2 en buenas condiciones y 2 en regulares condiciones en la región centro-sur del estado de Nuevo México durant años de sequía $(1993,1994)$. La vegetación climax existente fue de alrededor de $57 \%$ a $64 \%$ en los potreros clasificados bajo buenas condiciones y $32 \%$ a $37 \%$ en aquellos bajo regulares condiciones. Las cantidades totales de vida silvestre y aves (avistamientos $/ \mathrm{Km}^{2}$ ) durante el período de estudio fueron mas grandes $(P<0.10)$ en los potreros bajo condiciones regulares comparados con aquellos en buenas condiciones. El mismo número de especies de fauna silvestre fue visto tanto en los potreros bajo buenas como regulares condiciones. Avistamientos de codorniz (Callipepla squamata Vigors), torcazas (Zenaida macroura Linnaeus) antílope (Antilocarpa americana Ord) y conejo cola blanca del desierto (Sylvilagus auduboni Mearns) no mostraron diferencias $(\mathrm{P}>\mathbf{0 . 1 0})$ en la comparación de potreros en buenas y regulares condiciones. El número de avistamientos de liebres (Lepus californicus J.A. Allen) fue mas alto $(P<0.10)$ en los potreros bajo regulares condiciones. El estado de sequía existente durante 1994 redujo severamente $(P<0.01)$ el número de avistamientos de fauna silvestre en comparación con el año 1993 cuando las condiciones de precipitación estuvieron cercanas al promedio normal. El efecto años fue significativo $(P<0.10)$ para el avistamiento de especies como liebres, torcazas, cuervos (Corvus corax Gmelin), aves y total de fauna silvestre en general. El numero total de avistamientos durante 1994 se redujo en $42 \%$ comparado con 1993 (256 contra 440 avistamientos $/ \mathrm{Km}^{2}$ ) respectivamente.

vide better wildlife habitat than those in early seral, mid seral or climax ecological condition. This is because late seral rangelands support more diverse mixtures of grasses, forbs, and shrubs compared to mostly grasses on climax and mostly shrubs on mid or early seral rangelands (Holechek 1991). Replicated studies are needed to test this theory. The objective of our study was to compare wildlife numbers on 2 Chihuahuan Desert rangelands in late and 2 in mid seral condition in south-central New Mexico. Climate, soils, and topography are similar on the 4 study pastures.

\section{Materials and Methods}

\section{Study Area Description}

Our 4 study pastures were located on the NMSU Chihuahuan Desert Range Research Center (CDRRC). The ranch is 37 km 
north of Las Cruces, N.M. in Dona Ana County. The ranch is in the southem portion of the Jornada del Muerto Plains between the San Andres Mountains to the east and the Rio Grande Valley to the west. Elevation varies from 1,188 to $1,371 \mathrm{~m}$ with level or gently rolling hills.

\section{Soils}

Soils of the College Ranch area are mainly light loamy sandy loams underlain by calcium carbonate hardpan (caliche) at depths varying from a few centimeters to $1 \mathrm{~m}$ or more (Valentine 1970). They are classified as fine loamy, mixed, thermic, typic haplargids and are in the Simona-Cruces associations (SCS 1980). In areas where the ground cover is sparse, sandy dunes are formed around the invading mesquite plants (Wood 1969). Over most of the study area, the soil profile is relatively well preserved and stable.

\section{Climate}

The climate on the CDRRC is typical of the Chihuahuan Desert. The ranch is arid with an average of 200 days in the frost free period. The only permanent water sources are the wells and pipelines provided for livestock. Temperatures are high in summer, with a mean maximum of $36^{\circ} \mathrm{C}$ during June, and a mean maximum of $13^{\circ} \mathrm{C}$ during January (Pieper and Herbel 1982). Temperature differences are substantial between day and night. Solar radiation is generally greatest in June and lowest in December. Winds are strongest in the spring and cause severe erosion problems and water stress on the plants.

The annual precipitation is biomodal. Summer precipilation is generated from the Gulf of Mexico and is characterized by localized convectional storms of high intensity but low frequency.
Winter precipitation (December-February) comes from the Pacific Ocean. Storms in the winter are relatively gentle and evenly distributed. The mean annual precipitation is $230 \mathrm{~mm}$ with $52 \%$ of the annual rainfall occurring during the summer peak.

Rain gauges are located thruughout the CDRRC and extensive records were available. The total annual precipitation for the CDRRC in 1993 was $253 \mathrm{~cm}(107 \%$ of $\bar{x}$ ) (Fig. 1). In 1994 the total was $178 \mathrm{~cm}(76 \%$ of $\bar{x})$. In the 1994 growing season precipitation was near the all time low ( $41 \%$ of $x$ ), but above average in $1993(113 \%$ of $\bar{x})$. As a result, study pastures were destocked in August of 1994.

\section{Vegetation}

Primary grass species on our study areas include black grama (Bouteloua eriopoda Torr.), dropseed (Sporobolus sp.), threeawns (Aristida sp.), bush muhly (Muhlenbergia porteri Kunth.), fluffgrass (Erioneuron pulhellum Tateoka), and tobosa (Hilaria mutica Buckley). The most commonly encountered shrub species is honey mesquite (Prosopis glandulosa Torr.). It dominates the overstory and has been increasing over the past 100 years (Pieper and Herbel 1982). Other shrubs commonly found are snakeweed (Gutierrizea sarothrae Pursh), souptree yucca (Yucca elata av.), creosote (Larrea tridentata [Pursh] Nutt.), and fourwing saltbush (Atriplex canescens [Pursh] Nutt.). Leatherweed croton (Croton pottsii Lam.) is the primary forb occurring on the CDRRC and is an important food for livestock and pronghorn.

\section{Wildlife}

The wildlife on the CDRRC includes a variety of birds, and mammals. Gamebirds found on the ranch are the scaled quail

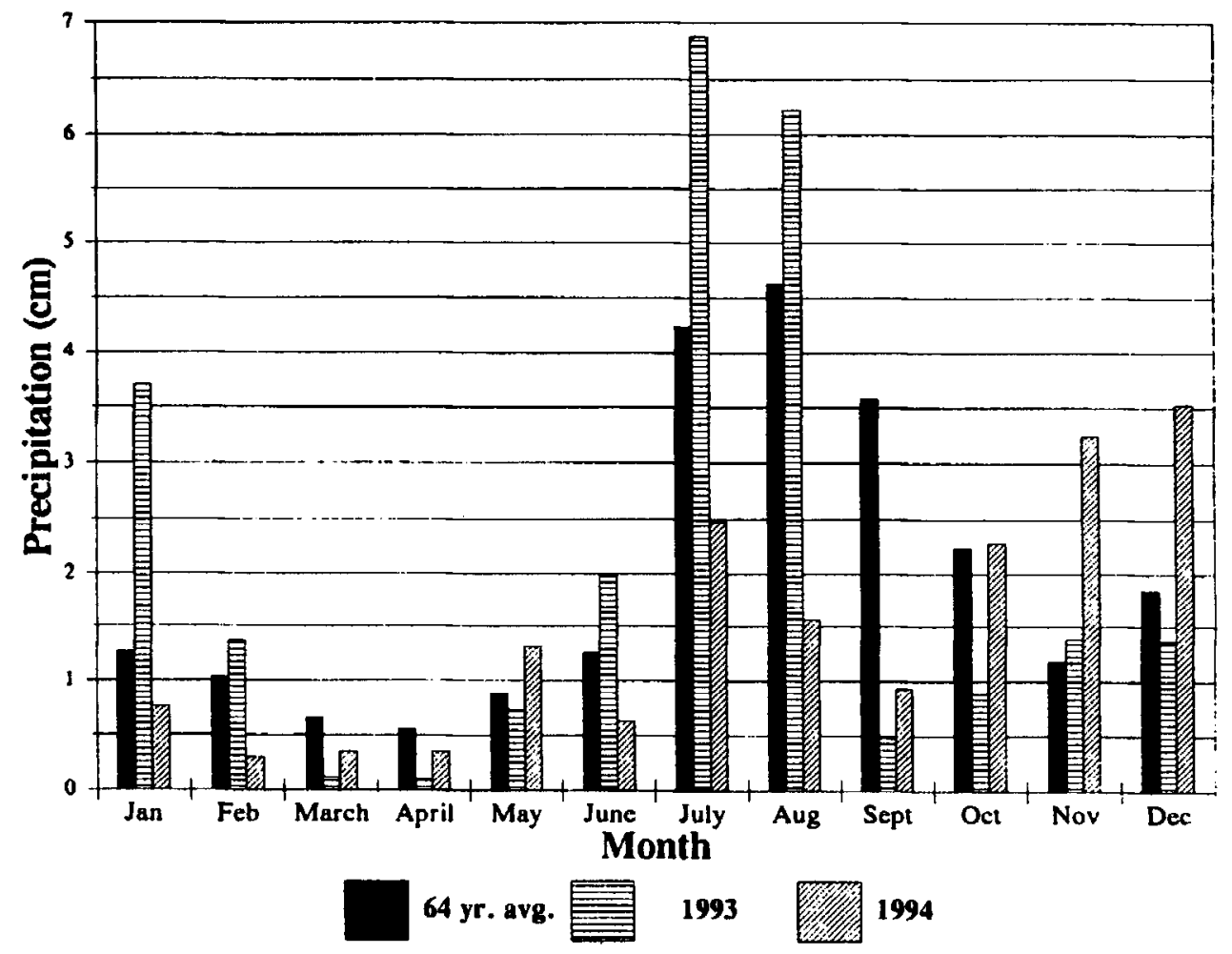

Fig. 1. Average monthly precipitation (cm) and monthly precipitation for 1993 and 1994 on the Chihuahuan Desert Rangeland Research Center in south central New Mexico. 
(Callipepla squamata Vigors) and mourning dove (Zenaida macroura Linnaeus). Raptors include the marsh hawk (Circus cyaneus Linnaeus), red-tailed hawk (Buteo jamaicensis Linnaeus), Swainsons hawk (Buteo swainsoni Bonaparte), American kestrel (Falco sparverius Linnaeus), and golden eagle (Aquila chrysaetos Linnaeus). Other raptors may be encountered infrequently. Songbird populations can vary substantially during the year (Davis et al. 1974). Primary songbird species include western meadowlark (Sturnella neglecta Audubon), western kingbird (Tyrannus verticalis Say), loggerhead shrike (Lanius ludovicianus Linnaeus), mockingbird (Mimus polyglottos Linnaeus), and various species of sparrows and juncos. The black-tailed jackrabbit (Lepus californicus J.A. Allen) and the desert cottontail (Sylvilagus anduboni Mearns) are the primary small mammals occurring on the ranch. Our study did not evaluate rodent populations on study pastures. The primary carnivore on the CDRRC is the coyote (Canis latrans Merriam). A few desert fox (Vulpes macrotis Merriam) have been observed in the past (Pieper et al. 1983). Large mammals include predominately pronghorn (Antilocapra americana Ord), with occasional sightings of mule deer (Odocoileus hemionus Rafinesque). The gemsbok (Oryx gazella Linnaeus), an introduced species from Africa, occurs primarily on the White Sands Missile Range and it has been occasionally sighted on the far east side of the CDRRC. Pieper et al. (1983) provide a detailed description of the wildlife present on the CDRRC.

\section{Research Pastures}

During 1991 four pastures with similar soils (sandy loams), topography (flat), and size were delineated and fenced. These include pasture $15(1,267 \mathrm{ha})$, pasture $4(974 \mathrm{ha})$, pasture $14(932$ ha), and pasture 1 (1,219 ha). The 4 pastures were adjacent to each other and surrounded by rangeland in a mid seral condition. Basically the spatial ordering of the pastures from west to east was 15, 14, 1, and 4. These pastures were stocked with equal proportions of 3 breeds of cattle (Brangus, Barzona, Beefmaster). At the initiation of the study (June 1992), pastures $15,4,14$, and 1 were stocked at the rates of $40,52,24$, and $32 \mathrm{AU}$ 's, respectively. Pastures 15 and 4 were considered to be in late seral (good) ecological condition and pastures 14 and 1 were considered to be in mid seral (fair) ecological based on ecological scores using the quantitative climax approach of Dyksterhuis (1949) (Table 1). Remaining climax vegetation was $64 \%$ on pasture 4 and $57 \%$ on pasture 15 . About $37 \%$ and $32 \%$ of the climax vegetation remained on pastures 14 and 1 , respectively. Pastures 15 and 4 were stocked to obtain a utilization level of about $30-35 \%$ on key forage species while pastures 14 and 1 were stocked to obtain a utilization level of $40-45 \%$.

Table 1. Percentages of open grassland, mixed grass-shrub, and shrubland on pastures $15,4,14$, and $1^{1}$.

\begin{tabular}{|c|c|c|c|}
\hline Pasture & $\begin{array}{l}\text { Open grassland } \\
\text { late seral condition }\end{array}$ & $\begin{array}{l}\text { Mixed grass-shrub } \\
\text { mid seral condition }\end{array}$ & $\begin{array}{l}\text { Shrubland } \\
\text { early seral condition }\end{array}$ \\
\hline & & $(\%)$ & 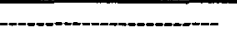 \\
\hline 15 & 59 & 35 & 6 \\
\hline 4 & 49 & 51 & 0 \\
\hline 14 & 55 & 21 & 24 \\
\hline 1 & 40 & 51 & 9 \\
\hline
\end{tabular}

Determinations were made by Dr. Dee Galt, a certified range consultant.

${ }^{2}$ This category included small areas that were near or at climax ecological condition.
In June 1993 five transects $1.6 \mathrm{~km}$ in length were systematically placed in each pasture. Transects were placed at least $1 \mathbf{~ k m}$ from boundary fences to minimize any ecotone effects where pastures adjoined. All transects were at least $0.8 \mathrm{~km}$ apart. These transects ( 5 per pasture) were used to monitor wildlife populations and plant foliar cover.

Foliar cover data were collected for summer 1993, fall 1993, summer 1994, and fall 1994. A modification of the line-intercept (Holechek and Stephenson 1983) procedure of Canfield (1941) was used to determine percent cover. A meter stick was used instead of an extended line. Measurements were made approximately every 80 meters. This resulted in 20 sampling points of 1 meter each along each $1.6 \mathrm{~km}$ transect. The meter stick was placed perpendicular to the transect and the intercept of the plants measured according to Bonham (1989). The intercept for grasses, forbs, and shrubs, were measured at the crown intercept. Measurements were recorded in millimeters.

Wildlife sightings were recorded along all 20 transects. These inventories were taken in late spring 1993, late summer 1993, late fall 1993, spring 1994, summer 1994, and fall 1994. All inventories were conducted between the hours of 0700 and 1100 . Binoculars were used to aid in the identification of species. Only wildlife observed within $50 \mathrm{~m}$ on either side the observer were recorded in an effort to avoid recording the same line twice. The same observer was used in order to maintain consistency in wildlife identification. Data were converted to wildlife sightings per $\mathrm{km}^{2}$ for statistical evaluation.

\section{Statistical Analysis}

A randomized factorial analysis of variance was used to compare vegetation, foliar cover and wildlife sightings among pastures and seasons (Steel and Torrie 1980). Pasture 15 and 4 were used as replicates for late seral range and pastures 1 and 14 were used as replicates for mid seral range. The Shannon index (Barbour et al. 1987, Magurran 1988) was used to evaluate vegetation and wildlife diversity on late and mid seral condition ranges.

\section{Results and Discussion}

Total wildlife sightings were higher $(P<0.01)$ on mid than late seral pastures (Tables 2 and 3). Wildlife diversity, measured by the Shannon index, did not differ $(P>0.10)$ between late and mid seral ranges (1.82 versus 2.02 ).

Total mammal sightings were higher on mid than on late seral ranges (Tables 2 and 3). This was primarily from the higher number $(P<0.05)$ of black-tailed jackrabbits observed on the mid seral pastures. Daniel et al. (1993b) also observed higher blacktailed jackrabbit numbers on mid compared to late seral Chihuahuan Desert rangelands.

Forbs, particularly leatherweed croton, are important in blacktailed jackrabbit diets throughout the year (Wansi 1989 , Schneberger 1990, Daniel et al. 1993a). The higher availability of forbs on the mid compared to late seral pastures may explain the difference in jackrabbit numbers (Table 4). Shrub and grass cover were similar on late and mid seral study areas.

Pronghom were observed more frequently on the late compared to mid seral pastures. Key pronghorn food plants such as globemallow (Sphaeralcea sp.) (Howard et al. 1990) were similar in availability among mid and late seral pastures as was shrub cover. 
Table 2. Summary of ecological condition, year, and season main effects for wildlife sightings (sightings/km²) in the Chihuahuan Desert of south-central New Mexico.

\begin{tabular}{|c|c|c|c|c|c|c|c|}
\hline \multirow{2}{*}{$\begin{array}{l}\text { Wildlife } \\
\text { species }\end{array}$} & \multicolumn{2}{|c|}{ Ecological condition } & \multicolumn{2}{|c|}{ Year } & \multicolumn{3}{|c|}{ Season } \\
\hline & Late & Mid & 1993 & 1994 & Spring & Summer & Fall \\
\hline & $\cdots \cdots$ & $\ldots \ldots$ & $\ldots \ldots$ & $\overline{\left(\mathrm{km}^{2}\right)--}$ & $\ldots .$. & $---\cdot--$ & -- \\
\hline Pronghorn & 9.3 & 0.5 & 8.7 & 1.6 & 2.4 & 10.8 & 2.3 \\
\hline Coyote & 0.5 & 3.1 & 1.0 & 1.6 & 1.6 & 1.6 & 4.6 \\
\hline Jackrabbit & $49.1^{\mathrm{a}}$ & $63.4^{b}$ & $64.8^{\mathrm{a}}$ & $47.7^{b}$ & 60.6 & 49.8 & 58.3 \\
\hline Cottontail & 8.1 & 12.4 & 11.4 & 8.8 & 11.6 & 10.1 & 8.6 \\
\hline Total Mammals & 67.1 & 79.6 & 86.5 & 61.2 & 76.2 & 72.4 & 72.9 \\
\hline Mourning dove & 12.4 & 19.3 & $25.2^{\mathrm{a}}$ & $6.7^{b}$ & $20.7^{\mathrm{a}}$ & $27.2^{\mathrm{a}}$ & $0.0^{\mathrm{b}}$ \\
\hline Scaled quail & 8.1 & 16.2 & 12.4 & 11.4 & 8.6 & 11.6 & 15.6 \\
\hline Total gamebirds & 20.5 & 35.5 & 37.6 & 18.1 & 14.6 & 19.4 & 7.8 \\
\hline Meadow lark & 5.2 & 14.9 & 11.9 & 8.3 & 12.4 & 11.7 & 6.2 \\
\hline Western kingbird & 18.0 & 20.5 & 26.4 & 17.1 & 36.6 & 21.0 & 0.0 \\
\hline Loggerhead shrike & 6.2 & 13.1 & 14.5 & 4.6 & 8.6 & 14.0 & 6.2 \\
\hline Sparrow/juncos & 110.7 & 138.7 & 143.1 & 106.8 & 127.5 & 140.0 & 107.3 \\
\hline Mockingbird & 6.2 & 14.9 & 11.9 & 8.8 & 21.0 & 17.9 & 1.6 \\
\hline Lark bunting & 20.5 & 42.9 & 62.7 & 4.4 & 0.0 & 95.6 & 0.0 \\
\hline Other songbirds & 4.9 & 23.9 & 114.8 & 46.5 & 24.0 & 14.0 & 2.3 \\
\hline Total songbirds & $171.7^{\mathrm{a}}$ & $268.7^{b}$ & $284.4^{\mathrm{a}}$ & $155.0^{b}$ & $230.0^{\mathrm{a}}$ & $307.1^{\mathrm{a}}$ & $122.1^{b}$ \\
\hline Total raptors & 13.1 & 16.8 & 14.50 & 14.00 & $15.6^{\mathrm{a}}$ & $18.7^{2}$ & $8.5^{\mathrm{b}}$ \\
\hline Ravens & 10.1 & 11.8 & $11.92^{\mathrm{a}}$ & $7.27^{\mathrm{b}}$ & 15.6 & 7.8 & 9.3 \\
\hline Total other birds & 10.6 & 12.4 & 15.55 & 7.27 & 17.1 & 7.8 & 9.3 \\
\hline Total birds & $215.9^{a}$ & $333.4^{\mathrm{b}}$ & $352.15^{a}$ & $194.38^{b}$ & $277.3^{\mathrm{a}}$ & $353.0^{\mathrm{b}}$ & $147.7^{c}$ \\
\hline Total wildlife & $282.0^{\mathrm{a}}$ & $413.0^{b}$ & $439.55^{a}$ & $255.55^{b}$ & $370.1^{b}$ & $444.7^{\mathrm{a}}$ & $227.8^{c}$ \\
\hline
\end{tabular}

Means within each main effect with different superscripts differ at $P<0.10$.

Therefore we believe the higher proportion of open grassland in the late compared to mid seral pastures (Table 1) explains why they had more pronghorn sightings. Yoakum (1972) reported open grasslands receive greater use by pronghorn than shrubgrasslands. This preference by pronghorn for open grasslands is due to better ability to detect predators and fewer obstacles that impede mobility when evading predators. Our results are consistent with those of Clemente (1993) who found that pronghorn used Chihuahuan Desert ranges in late seral condition more than ranges in lower or higher successional stages. We recognize our data are not conclusive due to the limited number of total pronghorn sightings on the study pastures.

More total bird sightings and more species of bird sightings occurred on mid compared to late seral pastures. The primary bird category observed on all study pastures was songbirds. We believe that higher amounts of open grassland explain the lower bird populations on the late seral pastures. Davis et al. (1974) studied bird populations on areas with varying densities of shrubs in the Chihuahuan Desert. They found bird diversity was greater on areas supporting a shrub component compared to open grasslands.

Scaled quail sightings did not differ $(P>0.10)$ on late and mid seral ranges. However total observations were twice as high on mid compared to late seral pastures. Scaled quail numbers on the study area were probably depressed because of extended drought. Numbers of scaled quail per $\mathrm{km}^{2}$ were lower in our study than in other studies on the CDRRC when rainfall was higher (Saiwana 1990, Smith 1993). The low number of scaled quail observations prevent drawing definite conclusions regarding how they respond to late and mid seral rangelands. In an earlier study under higher rainfall Saiwana (1990) found no differences $(P>0.05)$ in scaled quail numbers between late and mid seral Chihuahuan Desert rangelands but there was a tendency for quail observations to be higher on mid seral areas. He found areas with mixtures of grasses, forbs, and shrubs had much higher scaled quail populations than grasslands and slightly higher populations than shrublands. Smith et al. (1996) found scaled quail were nearly absent from climax Chihuahuan Desert rangelands while quail sightings were common on late seral rangelands. Our scaled quail data tènd to support the suggestion by Saiwana (1990) that about 45-55\% remaining climax vegetation best meets the needs of scaled quail in the Chihuahuan Desert.

Shrubs and half shrubs such as honey mesquite and broom snakeweed are important to scaled quail for both food and cover (Davis et al. 1974). These plants are considered to be increasers and are absent or occur at low levels on ranges in climax condition (Smith 1993). Campbell et al. (1973) speculated that vegetation changes caused by moderate cattle grazing can improve habitat conditions for scaled quail by opening dense stands of grass and increasing forb and shrub levels. Our results and those of Bock et al. (1984) and Smith (1993) support this speculation.

Mourning dove sightings did not differ $(P>0.01)$ on late compared to mid seral ranges. Saiwana (1990) reported no difference in mourning dove sightings on mid and late seral Chihuahuan Desert rangelands. Smith (1993) found open grasslands with few forbs and shrubs had lower numbers of mourning doves than Chihuahuan Desert rangelands with mixtures of grasses, forbs, and shrubs. In Arizona, Bock et al. (1984) found mourning dove populations were higher on grazed than ungrazed areas. In South Texas heavily grazed areas had higher mourning dove populations than those that were moderately grazed (Baker and Guthery 1990). This was explained by higher food availability on the heavily grazed areas.

Redroot pigweed (Amaranthus pubescens [Uline and Bray] RYBO.) and leatherwood croton are important mourning dove foods in southern New Mexico (Davis and Anderson 1973). Leatherweed croton was more available on the mid compared to late seral pastures (Table 4). Redroot pigweed is most prevalent around watering points that have been heavily grazed by live- 
stock (Fusco 1993). Mourning doves make considerable use of honey mesquite for nesting and roosting (Soutiere and Bolen 1976). Based on our research and Saiwana's (1990) it appears rangeland in either mid or late seral stages meets the needs of mourning doves in the Chihuahuan Desert.

Total songbird numbers were higher $(P<0.01)$ on the mid compared to late seral pastures. Vegetation diversity was similar $(P>0.10)$ on late and mid seral pastures (1.53 versus 1.63). However, late seral pastures had a higher proportion of open grasslands and a lower proportion of area with mixtures of grasses, forbs, and shrubs than mid seral pastures (Table 1).

Studies by Davis et al. (1974), Bock et al. (1984), and Smith (1993) indicate that Chihuahuan desert rangeland in a mid seral condition with about $45-55 \%$ remaining climax vegetation maximizes songbird diversity and numbers. However some species such as Cassins sparrow (Aimophila cassinii Woodhouse) may use only those rangelands at or near the climax (Bock et al. 1984). The late seral pastures in our study included small areas in the early seral stage, and larger portions in late seral or climax stages. In contrast areas in climax were almost absent from the mid seral pastures but a large early seral area did occur within pasture 14 (Table 1). Our research indicates that a mixture of pastures in climax, late seral, and mid seral stages will better meet the needs of songbirds in the Chihuahuan Desert than large continuous tracts of climax or late seral rangeland. This would probably also apply to gamebirds (scaled quail and mourning doves), and raptors.

Drought in 1994 reduced $(\mathrm{P}<0.10)$ black-tailed jackrabbit, mourning dove, songbird, raven, and in general birds and total wildlife sightings compared to 1993 when near average precipitation conditions occurred (Tables 2 and 3). This reduction is probably explained by a lack of high quality vegetation and insects in 1994 compared to 1993.

Total songbird and mourning dove sightings differed $(P<0.10)$ among seasons (Tables 2 and 3). Numbers were highest in summer, intermediate in spring, and lowest in fall. These changes are probably due to availability of food and cover, and temperature. Most songbirds and mourning doves are migratory and leave the

Table 3. Wildlife sightings (sightings $/ \mathrm{km}^{2}$ ) on late seral (LS) and mid seral (MS) study areas in the Chihuahuan Desert of south central New Mexico.

\begin{tabular}{|c|c|c|c|c|c|c|c|c|c|c|c|c|}
\hline \multirow[b]{2}{*}{ Species } & \multicolumn{2}{|c|}{$\begin{array}{c}\text { Late } \\
\text { Spring } 1993 \\
\end{array}$} & \multicolumn{2}{|c|}{$\begin{array}{c}\text { Late } \\
\text { Summer } 1993\end{array}$} & \multicolumn{2}{|c|}{ Fall 1993} & \multicolumn{2}{|c|}{ Spring 1994} & \multicolumn{2}{|c|}{ Summer 1994} & \multicolumn{2}{|c|}{ Fall 1994} \\
\hline & LS & MS & LS & MS & LS & MS & LS & MS & LS & MS & LS & MS \\
\hline & \multicolumn{11}{|c|}{ Mammals } & - \\
\hline Pronghom & 6.2 & 3.1 & 40.0 & 3.1 & 0 & 0 & 0 & 0 & 0 & $\mathbf{0}$ & 9.3 & 0 \\
\hline Coyote & $\mathbf{0}$ & 0 & 0 & 6.2 & 0 & 0 & 0 & 6.2 & 0 & 0 & 3.1 & 6.2 \\
\hline Jackrabbit & $56.0^{a}$ & $71.5^{b}$ & $52.9^{2}$ & $65.3^{a}$ & $62.2^{\mathrm{a}}$ & $80.9^{b}$ & 56.0 & 59.1 & $37.3^{\mathrm{a}}$ & $43.5^{\mathrm{b}}$ & $31.1^{\mathrm{a}}$ & $59.1^{\mathrm{b}}$ \\
\hline Cottontail & 6.2 & 12.4 & 6.2 & 15.6 & 12.4 & 15.6 & 9.3 & 18.7 & 9.3 & 9.3 & 3.1 & 3.1 \\
\hline Total & 68.4 & 87.1 & 100 & 90.2 & 77.1 & 96.4 & 65.3 & 84.0 & 46.7 & 52.9 & 49.8 & 68.4 \\
\hline \multicolumn{13}{|l|}{ Gamebirds } \\
\hline Mouming dove & 30.0 & 40.4 & 21.8 & 59.1 & 0 & $\mathbf{0}$ & 12.4 & 0 & 12.4 & 15.6 & $\mathbf{0}$ & 0 \\
\hline Scaled quail & 18.7 & 12.4 & 9.3 & 24.9 & 9.3 & $\mathbf{0}$ & 3.1 & 0 & 6.2 & 6.2 & 0 & 52.9 \\
\hline Total & 46.7 & 52.9 & 31.1 & 84.0 & 9.3 & 0 & 15.6 & 0 & 18.6 & 21.8 & 0 & 52.9 \\
\hline \multicolumn{13}{|l|}{ Songbirds } \\
\hline Meadowlark & 3.1 & 21.8 & 0 & 28.0 & 12.4 & 6.2 & 9.3 & 15.6 & 0 & 18.7 & 6.2 & 0 \\
\hline W. kingbird & 46.7 & 37.3 & 15.6 & 28.0 & 0 & 0 & 31.1 & 31.1 & 15.6 & 24.9 & 0 & 0 \\
\hline Loggerhead shrike & 3.1 & 21.8 & 15.6 & 28.0 & 9.3 & 9.3 & 6.2 & 3.1 & 3.1 & 9.3 & 0 & 6.2 \\
\hline Sparrow/juncos & 149.3 & 155.5 & 130.6 & 208.4 & 99.5 & 115.1 & 105.7 & 99.5 & 108.9 & 112.0 & 71.5 & 143.1 \\
\hline Mockingbird & 9.3 & 28.0 & 9.3 & 24.9 & $\mathbf{0}$ & 0 & 15.6 & 31.1 & 3.1 & 6.2 & 0 & 0 \\
\hline Lark bunting & 0 & 0 & 124.4 & 251.9 & $\mathbf{0}$ & 0 & 0 & 0 & 0 & 6.2 & 0 & 0 \\
\hline Hummingbird & 0 & 0 & 0 & 9.3 & 0 & 0 & 0 & 0 & 0 & 0 & 0 & 0 \\
\hline Crissal thrasher & 0 & 12.4 & 0 & 0 & 0 & 0 & 0 & 0 & 3.1 & 0 & 0 & 6.2 \\
\hline Scotts oriole & 6.2 & 3.1 & 0 & 0 & 0 & 0 & 3.1 & 0 & 0 & 0 & 0 & 0 \\
\hline Cactus wren & 0 & 9.3 & 0 & 12.4 & $\mathbf{0}$ & $\mathbf{0}$ & 0 & 0 & 0 & 0 & 0 & 3.1 \\
\hline Pyroloxia & 0 & 9.3 & 0 & 12.4 & 0 & 0 & 0 & 6.2 & 0 & 0 & 0 & 0 \\
\hline Cliff swallow & 0 & 0 & 0 & 3.1 & 0 & 0 & 0 & 0 & 0 & 0 & 0 & 0 \\
\hline Other & 3.1 & 28.0 & 6.2 & 0 & 0 & 0 & 3.1 & 12.4 & 3.1 & 6.2 & 0 & 0 \\
\hline Total & $220.0^{\mathrm{a}}$ & $326.6^{b}$ & $301.7^{\mathrm{a}}$ & $606.5^{b}$ & 121.3 & 130.6 & 174.2 & 199.0 & $136.8^{\mathrm{a}}$ & $183.5^{b}$ & $77.8^{\mathrm{a}}$ & $158.6^{b}$ \\
\hline \multicolumn{13}{|l|}{ Raptors } \\
\hline Marsh hawk & 0 & 0 & 0 & 0 & 3.1 & 6.2 & 0 & 0 & 0 & 3.1 & 3.1 & 0 \\
\hline Red-tailed hawk & 0 & 9.3 & 0 & 0 & 3.1 & 0 & 0 & 0 & 9.3 & 6.2 & 3.1 & 3.1 \\
\hline Swainson hawk & 9.3 & 12.4 & 12.4 & 9.3 & 0 & 0 & 15.6 & 9.3 & 6.2 & 6.2 & 0 & 0 \\
\hline Sparrow hawk & 0 & 0 & $\mathbf{0}$ & 0 & 0 & 0 & $\mathbf{0}$ & 0 & 9.3 & 3.1 & 0 & 6.2 \\
\hline Golden eagle & 0 & 6.2 & $\mathbf{0}$ & 0 & 0 & 6.2 & 0 & 0 & 0 & 0 & 0 & 0 \\
\hline Burrowing owl & 0 & 0 & 0 & 9.3 & 0 & 0 & 0 & 0 & 0 & 0 & 0 & 0 \\
\hline Total & $9.3^{\mathrm{a}}$ & $28.0^{\mathrm{b}}$ & $12.4^{2}$ & $18.7^{b}$ & $6.2^{2}$ & $12.4^{\mathrm{b}}$ & $15.6^{\circ}$ & $9.3^{b}$ & $24.9^{\mathrm{a}}$ & $18.7^{\mathrm{b}}$ & $6.2^{a}$ & $9.3^{b}$ \\
\hline \multicolumn{13}{|l|}{ Other Birds } \\
\hline Roadrunner & 3.1 & 0 & $\mathbf{0}$ & 0 & 0 & 0 & 0 & 0 & 0 & 0 & 0 & 0 \\
\hline Raven & 15.6 & 24.9 & 12.4 & 15.6 & 9.3 & 9.3 & 3.1 & 18.7 & 3.1 & 0 & 15.6 & 3.1 \\
\hline Nighthawk & 0 & 3.1 & 0 & 0 & 0 & 0 & 0 & $\mathbf{0}$ & 0 & 0 & 0 & 0 \\
\hline Total other birds & 18.7 & 28.0 & 12.4 & 15.6 & 9.3 & 9.3 & 3.1 & 18.7 & 3.1 & 0 & 15.6 & 3.1 \\
\hline Total wildlife & $363.1^{\mathrm{a}}$ & $522.6^{b}$ & $457.2^{\mathrm{a}}$ & $814.8^{b}$ & $223.2^{\mathrm{a}}$ & $248.8^{b}$ & $273.8^{\mathrm{a}}$ & $311.0^{b}$ & $230.1^{\mathrm{a}}$ & $276.8^{b}$ & $149.3^{\mathrm{a}}$ & $292.3^{b}$ \\
\hline
\end{tabular}

${ }^{\mathrm{a} b} \mathrm{Means}$ with seasons with different superscripts differ $P<0.10$. 
Table 4. Vegetation foliar cover (\%) on late seral (LS) and mid seral (MS) study areas in the Chihuahuan Desert of south central New Mexico.

\begin{tabular}{|c|c|c|c|c|c|c|c|c|c|c|}
\hline \multirow[b]{2}{*}{ Species } & \multicolumn{2}{|c|}{ Summer 1993} & \multicolumn{2}{|c|}{ Fall 1993} & \multicolumn{2}{|c|}{ Summer 1994} & \multicolumn{2}{|c|}{ Fall 1994} & \multicolumn{2}{|c|}{ Mean } \\
\hline & LS & $\mathbf{M S}$ & LS & MS & LS & MS & LS & MS & LS & $\mathbf{M S}$ \\
\hline Grasses & \multicolumn{10}{|c|}{ 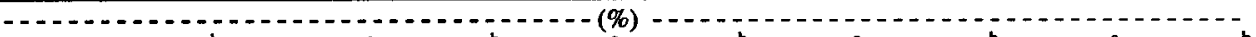 } \\
\hline Bouteloua eriopoda & $1.03^{\mathrm{a}}$ & $.28^{\mathrm{b}}$ & $1.84^{\mathrm{a}}$ & $.31^{\mathrm{b}}$ & $.38^{\mathrm{a}}$ & $.29^{\mathrm{b}}$ & $2.5^{\mathrm{a}}$ & $.19^{\mathrm{b}}$ & $1.44^{\mathrm{a}}$ & $.27^{\mathrm{b}}$ \\
\hline Sporobolus spp. & 1.47 & 1.62 & .94 & .55 & .81 & .98 & .85 & .66 & 1.02 & .93 \\
\hline Aristida spp. & 1.29 & 1.46 & 1.16 & .87 & .85 & .86 & .35 & 1.13 & .91 & 1.08 \\
\hline Erioneuron pulchellum & $.29^{\mathrm{a}}$ & $.49^{b}$ & $.04^{2}$ & $.18^{b}$ & $.25^{\mathrm{a}}$ & $.28^{2}$ & $.03^{\mathrm{a}}$ & $.09^{\mathrm{b}}$ & .15 & .26 \\
\hline Other grasses & .02 & .03 & 0 & 0 & 0 & 0.2 & .10 & .02 & .03 & .02 \\
\hline Total grasses & 4.10 & 3.88 & 3.98 & 1.91 & 2.29 & 2.34 & 2.83 & 2.08 & 3.55 & 2.56 \\
\hline \multicolumn{11}{|l|}{ Forbs } \\
\hline Sphaeralcea spp. & .08 & .08 & .01 & .03 & .06 & .10 & 0 & $\mathbf{0}$ & .04 & .05 \\
\hline Croton pottsii & $.30^{\mathrm{a}}$ & $.82^{b}$ & $.19^{\mathrm{a}}$ & $.38^{b}$ & $.31^{\mathrm{a}}$ & $.51^{b}$ & .11 & .11 & $.23^{\mathrm{a}}$ & $.46^{\mathrm{b}}$ \\
\hline Other forbs & .11 & .81 & .13 & .18 & .08 & .20 & .07 & .01 & .10 & .14 \\
\hline Total forbs & $.49^{\mathrm{a}}$ & $1.71 \mathrm{~b}$ & $.33 a$ & $.59^{\mathrm{b}}$ & $.45^{\mathrm{a}}$ & $.81^{\mathrm{b}}$ & $.18^{\mathrm{a}}$ & $.12^{b}$ & $.37^{\mathrm{a}}$ & $.65^{b}$ \\
\hline \multicolumn{11}{|l|}{ Shrubs } \\
\hline Gutierrezia sarothrae & .98 & 1.30 & .77 & .58 & .57 & .80 & 1.16 & .74 & .87 & .86 \\
\hline Prosopis glandulosa & .16 & .24 & .45 & .02 & .15 & .29 & .15 & .21 & .23 & .19 \\
\hline Yucca elata & .01 & .05 & .03 & .11 & 0 & .01 & .33 & .03 & .09 & .05 \\
\hline Other shrubs & .06 & .02 & .08 & .06 & .01 & .02 & .04 & .06 & .05 & .04 \\
\hline Total shrubs & 1.21 & 1.61 & 1.33 & .77 & .73 & 1.12 & 1.68 & 1.04 & 1.24 & 1.14 \\
\hline Total vegetation cover & 5.80 & 7.20 & 5.64 & 3.27 & 3.47 & 4.27 & 5.69 & 3.24 & 5.16 & 4.35 \\
\hline
\end{tabular}

${ }^{2} \mathrm{~B}$ Means within seasons with different superscripts differ at $\mathrm{P}<0.10$.

area when temperatures start to drop in October (Davis et al. 1974, Bock et al. 1984).

Livestock grazing pressure was heavier on the mid seral pastures compared to those in late seral stages. Generally, grazing pressure on the mid seral areas was considered moderate (40-45\% use of key forage species) while that on late seral pastures was considered conservative $(30-35 \%$ use of key forage species). Based on stubble heights and empirical observations of forage use, the mid seral pastures in our study were more lightly used and in better condition than most surrounding ranges controlled by the Bureau of Land Management. Although differential stocking may have partially confounded results from our study, our results indicate that range condition has far more influence on most wildlife species than stocking rate if livestock use levels are conservative to moderate ( $30-45 \%$ use). This could change if utilization levels were $50 \%$ or greater.

\section{Experimental Limitations}

Our wildlife enumeration technique involved tabulating animals along belts $100 \mathrm{~m}$ by $1.6 \mathrm{~km}$. We acknowledge that this procedure involves a certain amount of subjectivity by the observer regarding whether or not animals are in the census corridor. In order to minimize this source of error and distribute it evenly among transects, 1 well-trained, experienced observer (the senior author) did all enumerations.

Another problem with the technique is that in some cases animals that have been counted can move ahead of the observer, and potentially be counted again. Generally we believe the low level of wildlife encounters relative to distance traveled, the sparse nature of the vegetation, and the relatively flat terrain minimized this problem. We consider this source of error to be evenly distributed among transects in our study.

With the exception of pronghorn, observations were generally recorded for animals sighted within $50 \mathrm{~m}$ ahead or to the side of the observer (roughly a $100 \mathrm{~m}$ by $50 \mathrm{~m}$ rectangle). In the case of raptors and ravens which were often sighted well above the observer, considerable judgment was sometimes required in whether or not to record the sighting. In the case of pronghom, sightings were made $50 \mathrm{~m}$ or more from the observer. Pronghorn sighted within the census transect corridor were tabulated regardless of distance from the observer.

Brush cover was generally below the shoulder and of similar height on both the late and mid seral pastures. However visibility on shrubland compared to grassland areas was impaired to some extent. This could have caused underestimation of jackrabbits and possibly scaled quail on the brushier areas.

The Shannon index we used for wildlife and vegetation diversity measurements has 2 important assumptions (Magurran 1988). These are that individuals are randomly sampled from an "indefinitely large" population and that all species are represented in the sample. While we believe these assumptions generally hold for our study, we recognize there is not complete certainty on this matter.

\section{Management Implications}

Our two-year study of wildlife populations showed black-tailed jackrabbit and songbird populations to be higher on Chihuahuan Desert rangeland in mid compared to late seral ecological condition. Total wildlife observations also were higher on mid seral rangelands. Low sightings of pronghorn, scaled quail, and mourning doves prevented drawing definite conclusions for these species. However, there was a tendency for mourning dove and scaled quail sightings to be higher on mid seral rangelands and pronghorn sightings to be higher on those in the late seral stage.

Songbird populations showed considerable fluctuation among seasons and years. The drought conditions of 1994 depressed total songbird and total wildlife sightings compared to 1993 when precipitation conditions were near average. Total songbird sightings $/ \mathbf{k m}^{2}$ across pastures and seasons averaged 284 and 195 , respectively for 1993 and 1994 . Total wildlife sightings across seasons and pastures averaged 440 and 256 , respectively, for 1993 and 1994.

Our study indicates that Chihuahuan Desert rangelands in midseral condition provide more suitable habitat for many wildlife 
species than those habitats that are at or near the climax. Wildlife diversity in the Chihuahuan Desert would probably be maximized by maintaining a mosaic of pastures in mid seral, late seral, and climax ecological stages.

Large areas of late seral rangeland with $55-65 \%$ remaining climax appears desirable when the goal is multiple use. This type of rangeland provides high quality wildlife habitat, provides a reasonable monetary retum from livestock production, and maintains soil stability (Paulsen and Ares 1962, Holechek 1991, 1992, 1996). Research indicates a conservative stocking rate that removes $30-35 \%$ of key perennial grasses will permit progression of many mid seral Chihuahuan Desert rangelands to the late seral stage (Paulsen and Ares 1962, Holechek 1991; Holechek et al. 1994). Brush control will probably be required for meaningful improvement of Chihuahuan Desert rangelands in an early seral stage (Gibbens et al. 1986).

\section{Literature Cited}

Baker, D.L. and F.S. Guthery. 1990. Effects of continuous grazing on habitat and density of ground-foraging birds in South Texas. J. Range Manage. 43:2-6.

Barbour, M.G., J.H. Burk, and W.D. Pitts. 1987. Terrestrial Plant Ecology. Benjamin/Cummings Publishing Company, Inc. Menlo Park, Calif.

Bock, C.E., J.H. Bock, W.R. Kenney, and J.W. Hawthorne. 1984. Response of birds, rodents, and vegetation to livestock exclosure in a semi-desert grassland site. J. Range Manage. 37:239-243.

Bonham, C.D. 1989. Measurements for Terrestrial Vegetation. John Wiley and Sons. New York, N.Y.

Camphell, H., D.K. Martin, P.E. Ferkovich, and B.K. Farris. 1973. Effects of hunting and some other environmental factors on scaled quail in New Mexico. Wildl. Monogr. 34.

Canfield, R.H. 1941. Application of the line intercept method in sampling range vegetation. J. Forest. 39:388-394.

Clemente, F. 1993. Influences of range condition, cattle, and watering hold distribution on a pronghorn population in southcentral New Mexico. Ph.D. Thesis, New Mexico State Univ., Las Cruces, N.M.

Cutler, M.R. 1990. Appreciative use of wildlife - the recreational choice of three out of four Americans. pp. 25-32. In: Proc. from the conferences on: income opportunities for the private landowner through management of natural resources and recreational access. (Eds.) W. Grafton, A. Ferrise, D. Colyer, D. Smith, and J. Miller, West Virginia University Extension Service, Morgantown, W.V.

Daniel, A., J. Holechek, R. Valdex, A. Tembo, L. Saiwana, M. Fusco, and $M$. Cardenas. 1993a. Range condition influences on Chihuahuan desert cattle and jackrabbit diets. J. Range Manage. 46:296-302.

Daniel, A., J. Holechek, R. Valdez, A. Tembo, L. Saiwana, M. Fusco, and M. Cardenas. 1993b. Jackrabbit densities on fair and good condition Chihuahuan desert range. J. Range Manage. 46:524-528.

Davis, C.A. and W.M. Anderson. 1973. Seasonal food use by mourning doves in the Mesilla Valley, southcentral New Mexico. New Mexico Agr. Exp. Sta. Bull. 612.

Davis, C.A., P.B. Sawyer, J.P. Griffing, and B.D. Borden. 1974. Bird populations in shrub-grassland area, Southeastern New Mexico. New Mexico Agr. Exp. Sta. Bull. 619.

Dyksterhuis, E.J. 1949. Condition and management of rangeland based on quantitative ecology. J. Range Manage. 2:104-115.

Fusco, M. 1993. Grazing influences on watering point vegetation in the Chihuahuan desert. M.S. Thesis. New Mexico State Univ., Las Cruces, N.M.

Gibbens, R. P., C. H. Herbel, H. L. Morton, W. C. Lindemann, J. A. Ryder-White, D. B. Richman, E. W. Huddleston, W. H. Conley, C A. Davis, J. A. Reitzel, D. M. Anderson, and A. Guiao. 1986. Some impacts of 2,4,5-T on a mesquite duneland ecosystem in southern New Mexico: A synthesis. J. Range Manage. 39:320-326.
Holechek, J.L. 1991. Chihuahuan Desert rangeland, livestock grazing, and sustainability. Rangelands 13:115-120.

Holechek, J.L. 1992. Financial aspects of cattle production in the Chihuahuan Desert. Rangelands 14:145-149.

Holechek, J.L. 1996. Financial returns and range condition on southern New Mexico ranches. Rangelands 18:52-56.

Holechek, J.L. and T. Stephenson. 1983. Comparison of big sagebrush in northcentral New Mexico under moderately grazed and grazing excluded conditions. J. Range Manage. 36:455-456.

Holechek, J.L., A. Tembo, A. Daniel, M.J. Fusco, and M. Cardenas. 1994. Long-term grazing influences on Chihuahuan Desert rangeland. Southw. Nat. 39:342-349.

Howard, V.W., Jr., J.L. Holechek, R.D. Pieper, K. Green-Hammond, M. Cardenas, and S.L. Beasom. 1990. Habitat requirements for pronghorn on rangeland impacted by livestock and net wire in east central New Mexico. New Mexico Agr. Exp. Sta. Bull. 750.

Magurran, A.E. 1988. Ecological Diversity and its Measurement. Princeton Univ. Press. Princeton, N.J.

Paulsen, H.A., Jr. and F.N. Ares. 1962. Grazing values and management of black grama and tobosa grasslands and associated shrub ranges of the Southwest. USDA Forest Serv. Tech. Bull. 1270. Washington, D.C.

Pieper, R.D. and C.H. Herbel. 1982. Herbage dynamics and primary productivity of a desert grassland ecosystem. New Mexico Agr. Exp. Sta. Bull. 695.

Pieper, R.D., J.C. Amway, C.H. Herbel, R.L. Packard, S.L. Pimm, R.J. Raitt, E.E. Staffeldt, and J.G. Watts. 1983. Structure and function of North American desert grassland ecosystems. New Mexico Agr. Exp. Sta. Spec. Rep. 39.

SCS. 1980. Soil survey of Dona Ana county, New Mexico. Soil Cons. Serv., USDA.

Saiwang, L. 1990. Range condition effects on scaled quail in southcentral New Mexico. Ph.D. Thesis. New Mexico State Univ., Las Cruces, N.M.

Schneberger, A. 1990. Botanical diets and dietary overlap of blacktailed jackrabbits and cattle on black grama grassland. M.S. Thesis, New Mexico State Univ., Las Cruces, N.M.

Smith, G.T. 1993. Influence of excellent and good condition Chihuahuan Desert range on vegetation, cattle diets, and wildlife populations. M.S. Thesis. New Mexico State Univ., Las Cruces, N.M.

Smith, G., J.L. Holechek, and M. Cardenas. 1996. Wildlife numbers on excellent and good condition Chihuahuan Desert rangelands: an observation. J. Range Manage. 49:489-493.

Soutiere, E.C. and E.G. Bolen. 1976. Morning dove nesting on tobosa grass-mesquite rangeland sprayed with herbicides and burned. $\mathbf{J}$. Range Manage. 29:226-231.

Steel, R.G. and J.H. Torrie. 1980. Principles and Procedures of Statistics. McGraw-Hill Rook Co., New York, N.Y..

Valentine, K.A. 1970. Influence of grazing intensity on improvement of deteriorated black grama range. New Mexico State Univ. Agr. Exp. Sta. Bull. 533.

Wansi, T. 1989. Botanical content of black-tailed jackrabbit diets on semi-desert rangeland. M.S. Thesis, New Mexico State Univ., Las Cruces, N.M.

Wood, J.E. 1969. Rodent populations and their impact on desert rangelands. New Mexico State Univ. Agr. Exp. Sta. Bull. 555.22

Yoakum, J.D. 1972. Antelope-vegetative relationships. Antelope States Workshop Proc. 5:171-177. 